Acta vet. scand. $1970,11,59-72$.

From the State Veterinary Serum Laboratory, Copenhagen, Denmark.

\title{
DEMONSTRATION OF VD-VIRUS \\ BY THE FLUORESCENT ANTIBODY TECHNIQUE \\ IN TISSUES OF CATTLE \\ AFFECTED WITH BOVINE VIRAL DIARRHEA (MUCOSAL DISEASE)
}

\author{
By \\ A. Meyling
}

Bovine viral diarrhea (Olafson et al. 1946) and mucosal disease (Ramsey \& Chivers 1953), which are now considered one disease caused by VD-virus, have existed in Denmark for a number of years (Basse 1961, Nielsen 1961). A cytopathogenic VDvirus strain that could be compared serologically with the American type strain Oregon C24V was isolated in 1962 (Borgen 1963), and subsequent serological surveys showed that VD-virus infections were widespread among Danish cattle (Dinter \& Borgen 1964). Apart from the originally described syndromes VD-virus is involved in a number of clinical entities such as abortions in cattle and enteritis in newborn calves (Gillespie et al. 1968, Romvary 1965, Schipper \& Eveleth 1957), chronic wasting (French \& Snowdon 1964) and pneumoenteritis in calves (Bürki \& Germann 1964 ).

Specific and rapid means of detection of VD-virus are important for further studies of the epidemiology and pathogenesis of these conditions. The fluorescent antibody technique (FAT), which has been applied in the diagnosis of a large number of viral agents, has also been used for staining of VD-virus. For this purpose it was first used by Mengeling et al. (1963) who reported that the antigenic relationship between swine fever and VD-virus 
could be demonstrated by staining with FA. The technique was later used by others for demonstration of noncytopathogenic and cytopathogenic strains of VD-virus in tissue culture (Fernelius 1964, Kokles et al. 1967), but little has been published on the use of FA for the demonstration of VD-virus in tissues of infected animals (Peter et al. 1968). The present study gives an account of the results of such immunohistological examinations of tissues from naturally occurring cases of BVD-MD.

\section{MATERIALS AND METHODS}

Animals examined. In the majority of cases (52) the material examined consisted of more or less comprehensive tissue specimens sent to the laboratory from practising veterinarians and veterinarians at rendering plants. Only tissue material which appeared fresh and free from macroscopical signs of autolysis was processed for FA-staining.

In 7 cases it was possible to take out material from whole carcasses immediately or a few hours after the animals had died or been killed. Collection of specimens from these animals took place either at the Department of Pathology of The Royal Veterinary and Agricultural University or at a rendering plant. The animals include calves and heifers with lesions suggestive of BVD-MD.

Tissue culture. Primary cultures were produced from kidneys of calves ( $1-3$ weeks old) from a slaughterhouse. After trypsinization the cells were suspended in Earle's balanced salt solution (EBSS) with $0.5 \%$ lactalbumin, $0.01 \%$ yeast extract, $100 \mathrm{i}$. u. penicillin, $0.1 \mathrm{mg}$ streptomycin pr. $\mathrm{ml}$, and $10 \%$ calf serum. The same medium with $2 \%$ horse serum was used for maintenance.

The cells were seeded in Leighton tubes, which were inoculated $4-5$ days later when the cell layer was confluent.

Approximately $10 \%$ tissue suspensions were produced by grinding pieces of tissue in a mortar with EBSS with double amount of the above-mentioned antibiotics and 100 units of mycostatin per $\mathrm{ml}$. The tissue suspensions were centrifuged at 3000 r.p.m. for $1 / 2 \mathrm{hr}$., and $0.1 \mathrm{ml}$ of the supernatant was inoculated into each of 2 Leighton tubes. After 4-5 days' incubation at $37^{\circ} \mathrm{C}$ the coverslips were harvested, rinsed in PBS $(0.14$

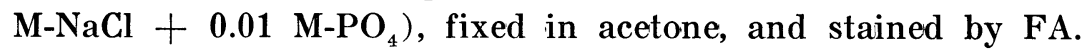


At least 5 normal cultures from each production of primary kidney cultures were examined as controls.

FA-technique. Sera for conjugation with FITC (fluoresceinisothiocyanate, Baltimore Biological Laboratories, Md., U.S.A.) were produced by hyperimmunizing goats with the VD-virus strain UG59. This strain, which is strongly cytopathogenic, has been isolated, identified, and compared serologically with the Oregon C24V-strain by Borgen (1963). Virus was passed on Roux flasks with primary calf kidney cultures. After 5 days' incubation, when about $80 \%$ of the cell layer was destroyed, the cells were frozen and thawed once and the medium thereafter clarified by centrifugation. Goats were given $2.5 \mathrm{ml}$ infective tissue culture fluid i. v., and $2.5 \mathrm{ml}$ i. $\mathrm{m}$. with $2.5 \mathrm{ml}$ complete Freund's adjuvant (Difco). Six weeks later 3 injections of $5 \mathrm{ml}$ 10 -fold concentrated virus were given i. $v$. at intervals of 1 week. The goats were bled weekly during the first 3 weeks after the last injection.

All sections were stained with a particularly potent conjugate which had been produced from a serum obtained after this prolonged immunization schedule. Further potent conjugates were made from sera of goats that had been subjected to a shorter course of immunization, and from convalescent bovine serum ${ }^{\star}$ ). The procedures of conjugation with FITC have been described previously (Meyling \& Bitsch 1967). The goat-serum conjugates were absorbed before use with lyophilized calf kidney tissue powder. The absorption was carried out overnight at $4{ }^{\circ} \mathrm{C}$ on a magnetic stirrer. The bovine conjugate was purified on a column packed with DEAE sephadex A 50 equilibrated with $0.10 \mathrm{M}$ TrisHCl buffer at pH 8.0 (Voss et al. 1967). A fraction of conjugate which stained infected cells brilliantly and was completely free from non-specific staining components was obtained by elution with $0.2 \mathrm{M}$ Tris buffer at $\mathrm{pH}$ 8.0.

Testing for non-specific staining was carried out on uninfected primary cultures using fractions of conjugate that had been concentrated to the original serum volume by dialysis against polyethylenglycol 20,000 (Koch-Light Laboratories, Ltd., Colnbrook, Bucks., England).

*) Kindly supplied by dr. Jos. Leunen, Institut de Recherches Vétérinaires, Bruxelles. 
Blocks of tissue were fixed to the tissue holders of the cryostat by freezing with dry ice and $6 \mu$ thick sections cut at a temperature of $-20^{\circ} \mathrm{C}$. The sections were picked up on slides, air-dried and fixed for $\mathbf{1 0} \mathrm{min}$. in acetone at room temperature. They were then covered with conjugate and incubated in a humid chamber at $37^{\circ} \mathrm{C}$.

From sites adjacent to those from which samples were chosen for immunofluorescence additional tissue blocks were removed and fixed in $4 \%$ neutral formalin. From these blocks conventional paraffin sections were prepared and stained with hematoxylin-eosin.

Microscopy was performed on a Reichert Zethopan microscope equipped with an HBO200 mercury lamp. With the darkground condensor in operation a UG1/1.5 mm filter was used as primary filter and a colourless ultraviolet light absorbing filter (GG13 + Wratten 2 B) as barrier filter. For microphotography with low-power objectives a bright-ground condensor was used, and in such cases the filter combination was BG12/6 $\mathrm{mm}$ as primary filter and OG1/1 mm + GG9/1 mm as barrier filter. Photomicrographs were taken with Kodak Tri-X-Pan (black and white).

\section{RESULTS}

In Table 1 a survey is given of the results obtained by FAstaining of cryostat sections of various tissues from 59 cattle which had shown clinical and pathological signs of BVD-MD, and from which one or more tissues were judged positive by FA.

A total of 316 tissue specimens were examined, and VD viral antigen was demonstrated in $270(85.4 \%)$. Primary calf kidney cultures were inoculated with tissue suspension made from at least one of the following tissues: small intestine, lung, kidney, and spleen. By this method VD-virus was demonstrated in 47 cases. The cultures inoculated with tissue suspensions from 6 cases were destroyed by bacterial or fungal growth before FAstaining was performed. In another 6 cases in which the cultures were apparently undamaged the staining results were negative. The distribution and intensity of fluorescence in sections of carcass material from these cases were characteristic of VD-virus, and in as much as the conjugate did not stain sections of normal tissue, the staining was considered specific in spite of the un- 
T a b l e 1. Results of FA-staining for VD-virus in tissues from 59 cattle affected with BVD-MD.

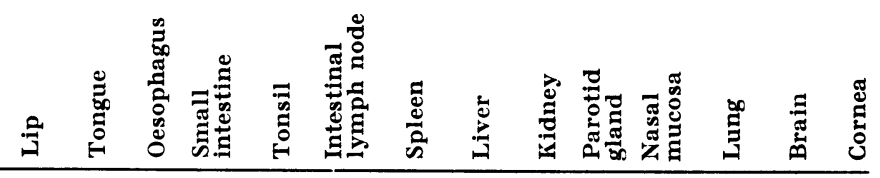

Total number of specimens stained $\begin{array}{llllllllllllll}18 & 15 & 8 & 49 & 10 & 41 & 41 & 17 & 37 & 9 & 18 & 37 & 10 & 6\end{array}$

Number of specimens judged positive $\begin{array}{llllllllllllll}18 & 15 & 8 & 44 & 9 & 39 & 30 & 12 & 31 & 9 & 18 & 21 & 10 & 6\end{array}$

Number of specimens judged negative

$\begin{array}{llllllllllllll}0 & 0 & 0 & 0 & 1 & 0 & 6 & 5 & 4 & 0 & 0 & 10 & 0 & 0\end{array}$

Number of specimens ${ }^{*}$ ) judged unfit

$\begin{array}{llllllllllllll}0 & 0 & 0 & 5 & 0 & 2 & 5 & 0 & 2 & 0 & 0 & 6 & 0 & 0\end{array}$

*) after microscopical examination.

successful attempts to demonstrate the virus in primary calf kidney cultures.

Although virus could be demonstrated in all kinds of tissue examined, its distribution varied considerably. Generally, it can be said that the degree of involvement was high in those tissues where the most pronounced pathological lesions were found, i.e. the oral and gastro-intestinal mucous membranes.

The intracellular specific fluorescence was cytoplasmic. The intensity of staining was highest around the nucleus, where smaller and larger granula were frequently found.

The mucous membranes of the mouth and forestomachs. The epithelia of the tongue, lips, and cheeks were always more or less involved. When the epithelium was intact the infection was usually limited to the basal cell layers. However, in some fields changes were found which were believed to represent the beginning of erosions (Fig. 1). In such areas the surface of the epithelium was slightly depressed, and below there were larger foci of infected cells involving all layers of the epithelium. In areas where the process had progressed further the cells in the center were destroyed and the lesion would appear as an erosion lined with fluoresceing cells.

The presence of the infection was less conspicuous in the propria. Here fluorescent cells were found in the walls and 
adventitia of the vessels. The immunohistological pattern in the oesophagus and in the forestomachs was essentially the same as in the oral mucosa.

Abomasal and intestinal mucosa. In 7 cases the whole animal was available for post-mortem examination, and samples could be taken from different parts of the intestinal tract. Usually, however, only a small piece of the intestine was available for examination. Viral antigen was demonstrated in the intestinal wall in all cases in which suitable specimens could be examined (44 cases).

Infected cells were abundant in the mucosa of the abomasum, small intestine, colon and rectum (Fig. 2). This however, could be seen only when the tissue was quite fresh and the lesions not too pronounced. In areas where the epithelium of the villi had sloughed off the infection could still be detected at the bottom of the crypts. When the typical cystic changes of the intestinal crypts were present the walls of the cysts were formed by flattened, fluoresceing epithelial cells.

Infected cells were always present in the submucosa and propria mucosae, partly in the walls of the vessels, partly in cuffs of histiocytic cells surrounding the vessels (Fig. 6). In the Peyer patches a few infected cells could be found in the germinal centers, but more often the whole follicle was involved.

The respiratory tract. Sections were made of the cartilaginous anterior part of the ventral turbinate. The epithelium was often infected, but the degree of involvement varied considerably in the different sections. Viral antigen was regularly demonstrated in the submucosal serous glands. (Fig. 3 ).

Virus was demonstrated in the lungs by FA in 21 out of 27 cases in which these organs were available for examination. Histological examination of H.E.-stained sections of formalinfixed tissue blocks from sites adjacent to those examined by FA revealed interstitial pneumonia with proliferation of mononuclear and histiocytic cells in the submucous and peribronchial tissue. By FA-staining infected cells were found in the epithelium of the smaller bronchi and in the above-mentioned submucous and peribronchial cell infiltrations. In some fields scattered infected cells were found in the thickened alveolar walls (Fig. 4).

The kidneys were examined in 37 cases and found positive in 31 cases. As a rule the number of infected cells was low, but the 
A. Meyling: VD-virus in tissues of cattle

PLATES 


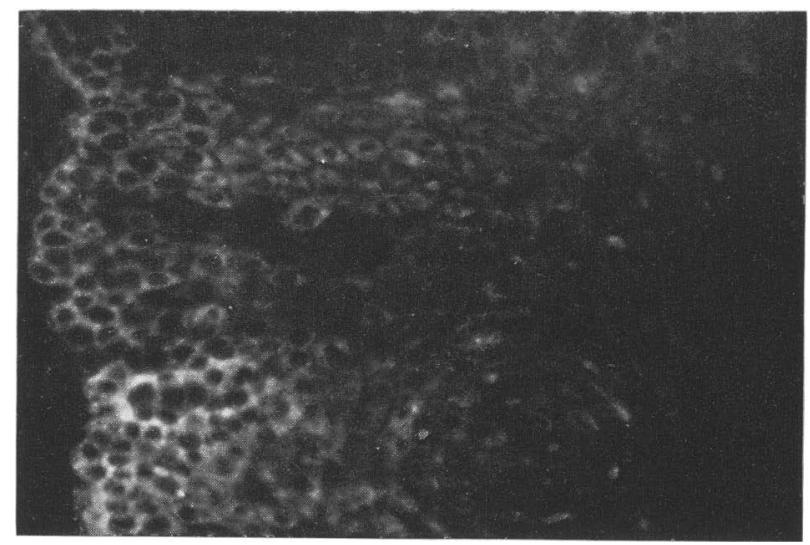

Figure 1. Infected cells in the epithelium of the tongue. A defect in the cell layer is seen in the center (J.no. 245/68-69, $250 \times$, dark ground).

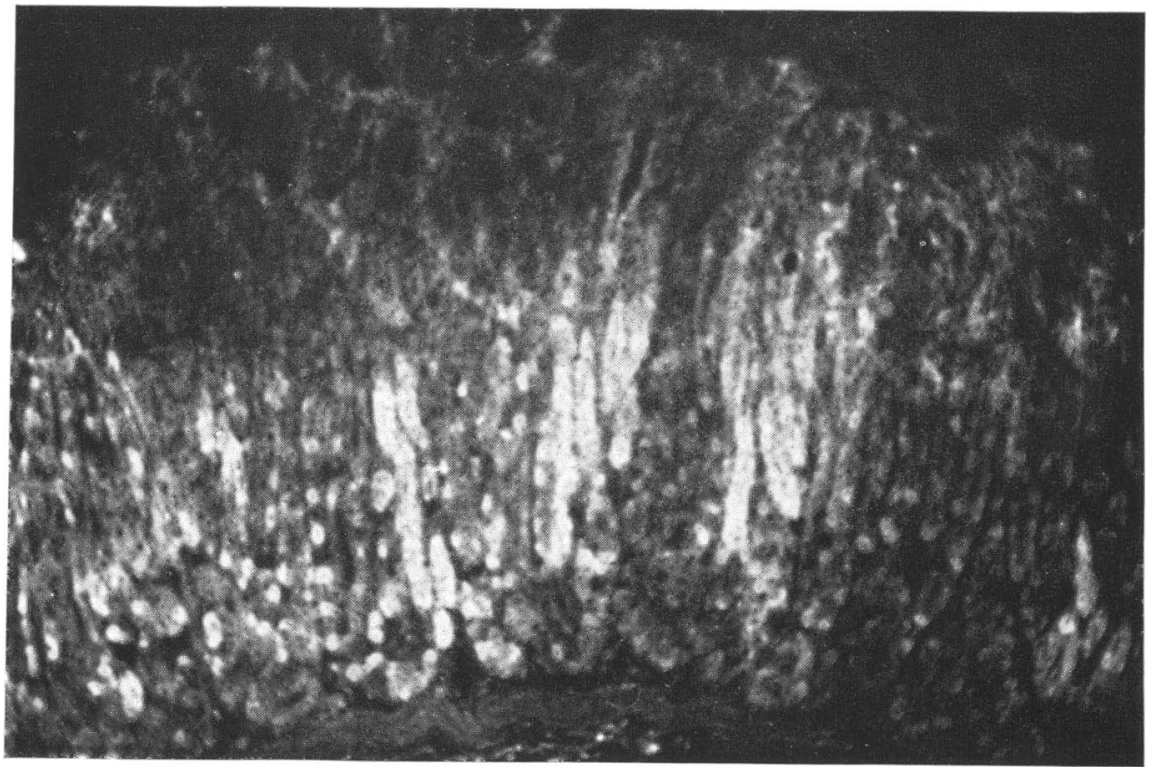

Figure 2. Infected glands in the abomasal mucosa $(\mathrm{K} \mathrm{2,68} \times$, bright ground). 


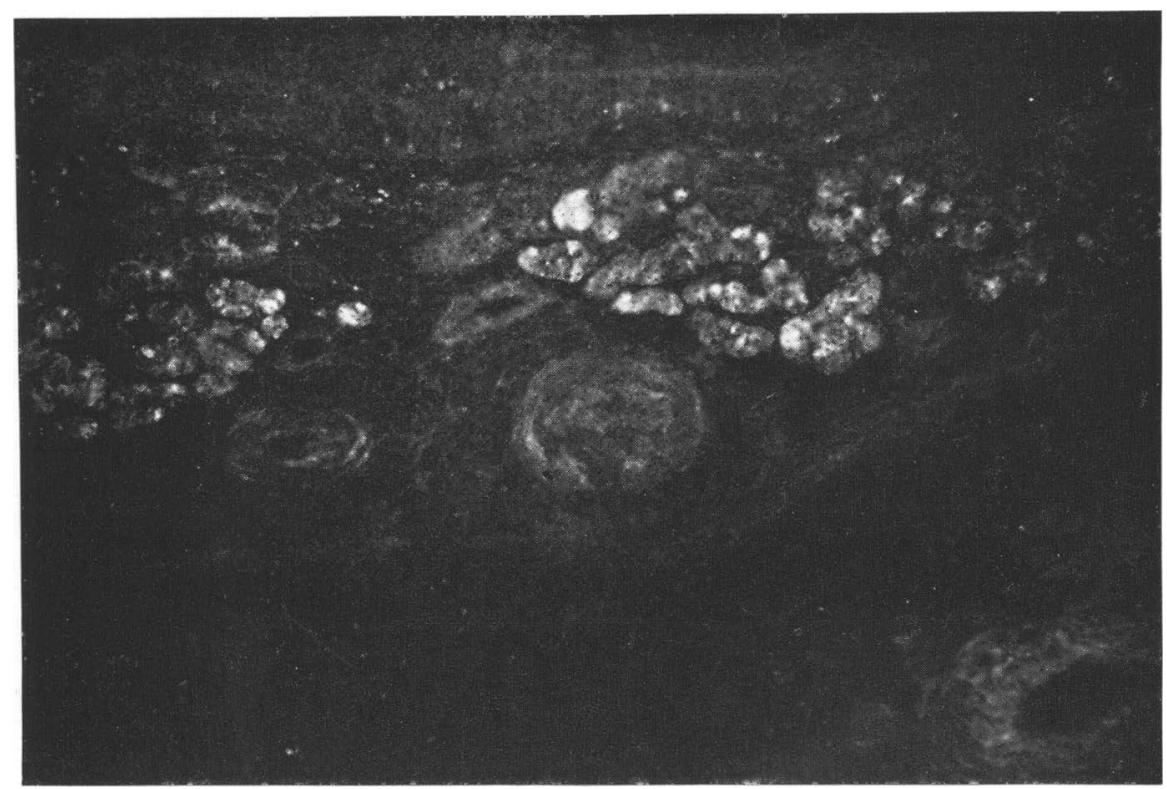

F i g u r e 3. Nasal mucosa. Infected glands and arteries in the submucosal tissues (K 3, $68 \times$, bright ground).

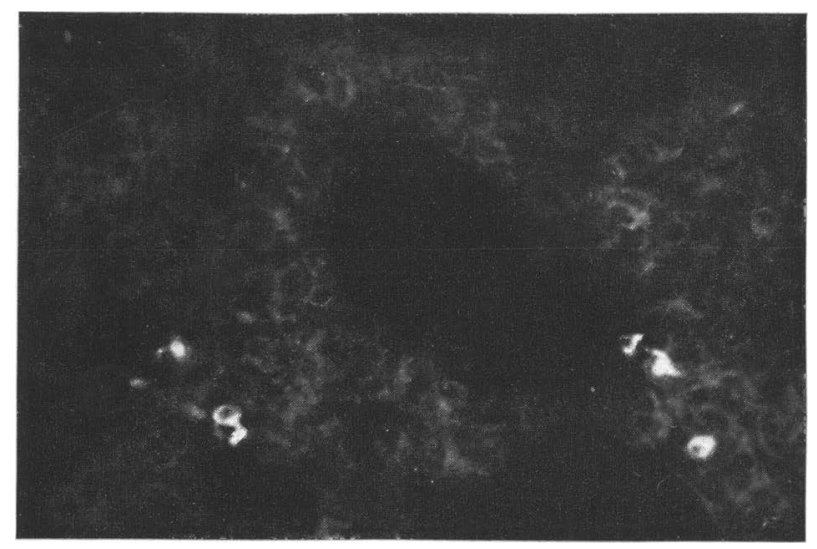

Figure 4. Lung. Infected cells in thickened alveolar walls (K 2, $250 \times$ ). 


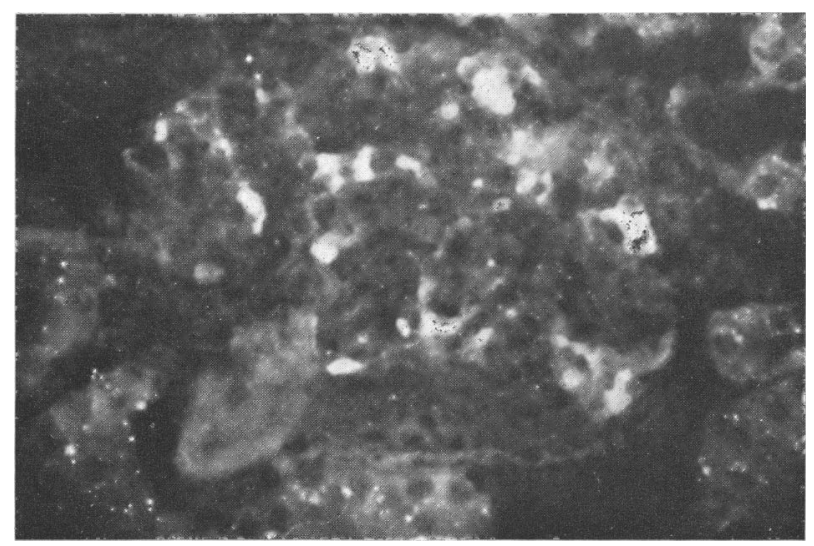

F i g u r e 5. Kidney. Infected cells in a glomerular tuft. $(\mathrm{K} 10,250 \times$, dark ground).

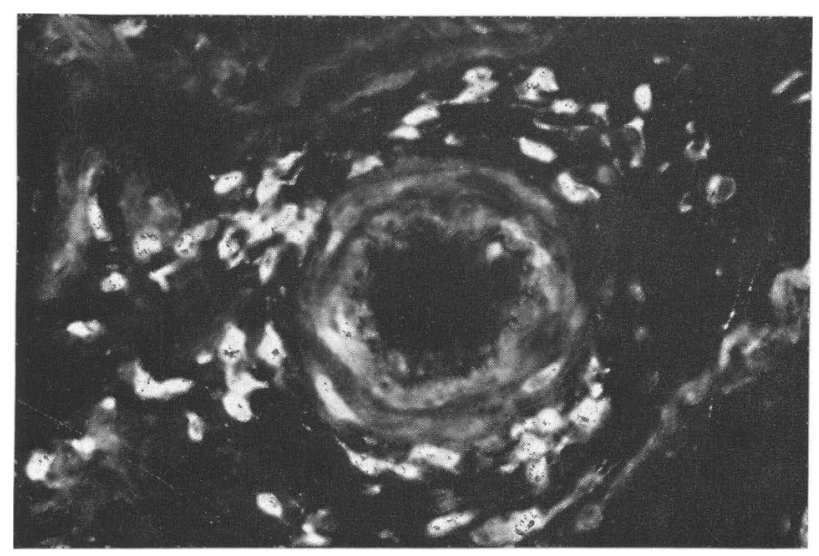

F ig u r e 6. Small artery in the intestinal mucosa $(\mathrm{K} \mathrm{2,} 250 \times$, dark ground).

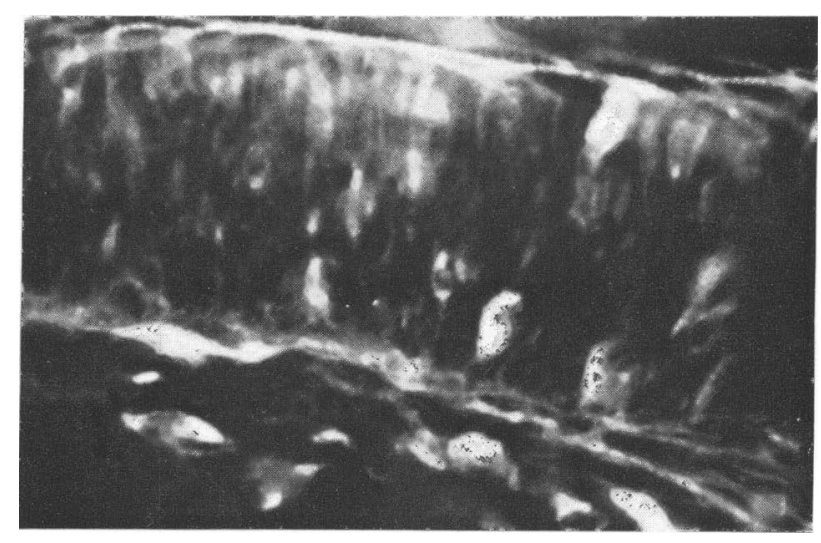

Figure 7. Arterial wall. Detached infected endothelial cells and infected cells in the media (J.no. 76/68-69, $625 \times$, dark ground). 


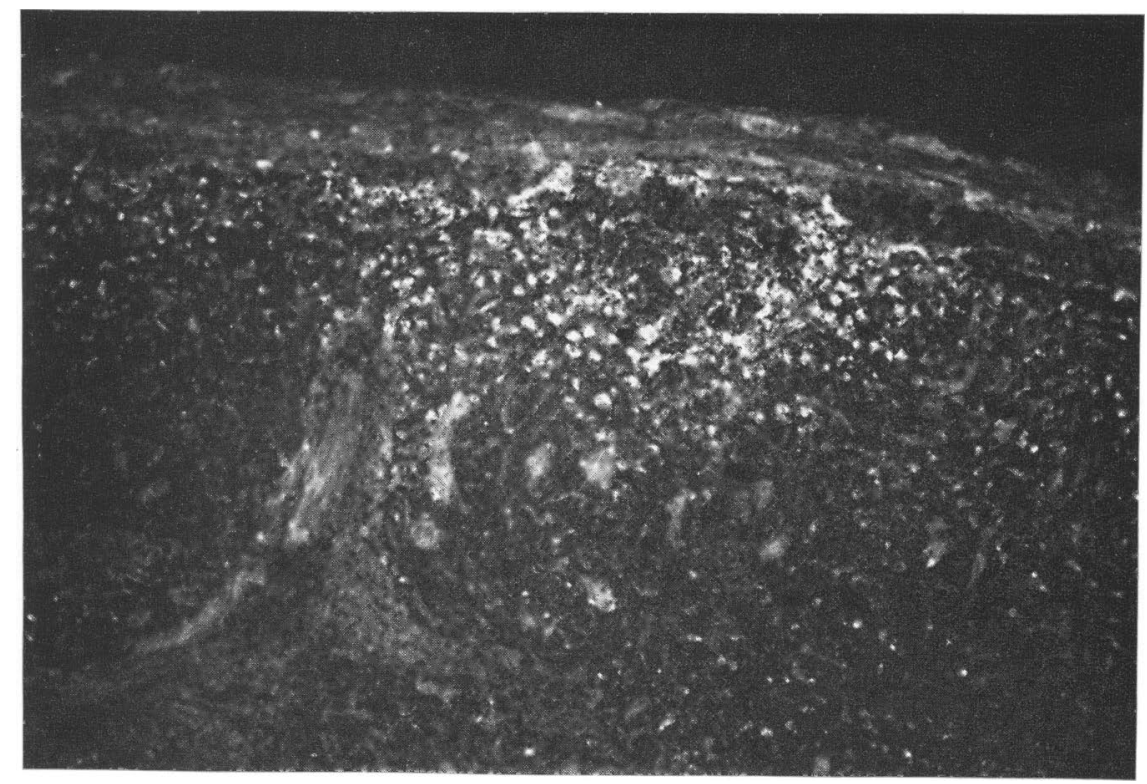

Figure 8. Intestinal lymph node. Focus of infected cells in the cortex and marginal sinus (K 2, $68 \times$, bright ground).

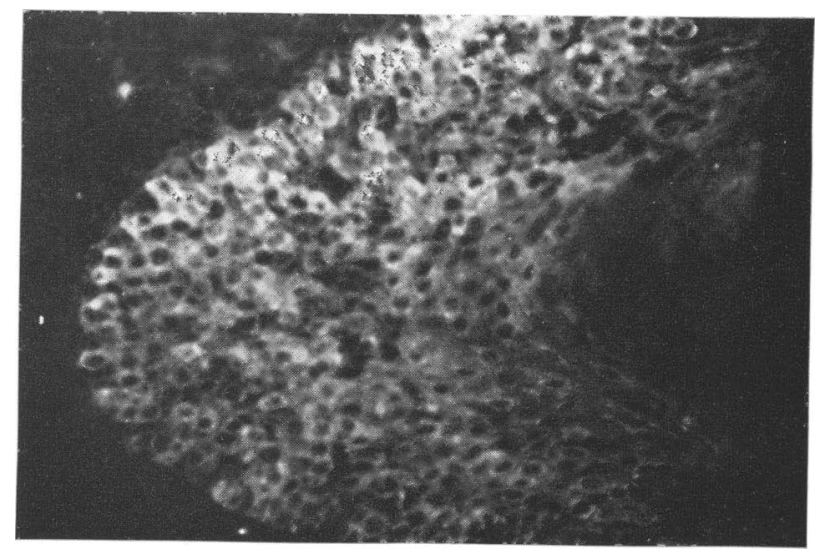

Figure 9. Infected cells at the bottom of a tonsillar crypt (K 1, $250 \times$, dark ground). 


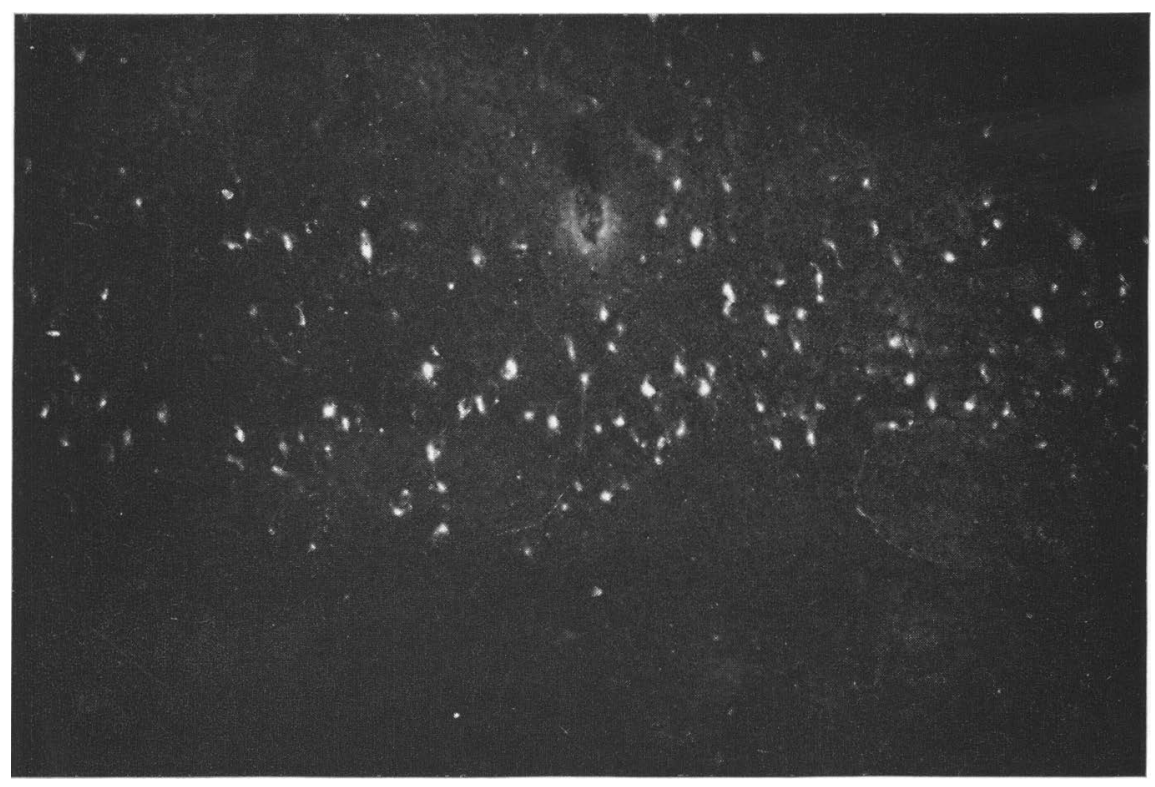

F i g u r e 10. Numerous infected neurons in the cerebral cortex (K 2, $68 \times$, bright ground).

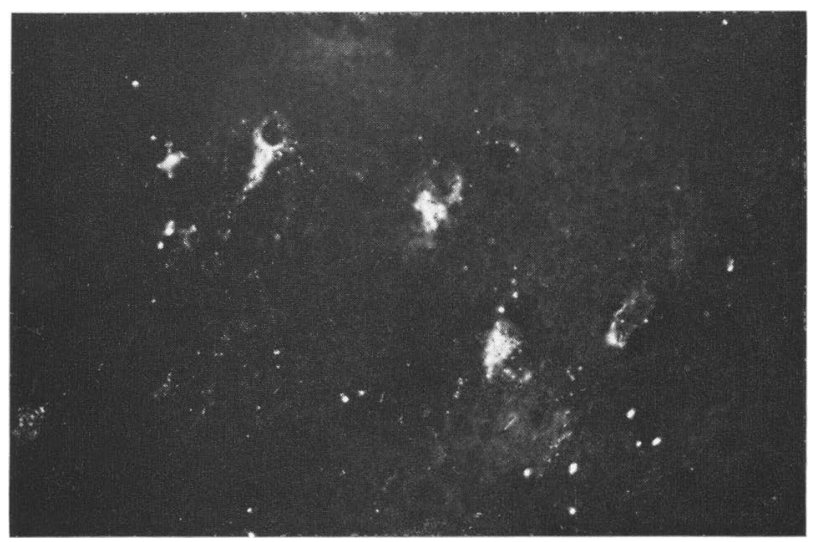

F i g u r e 11. Large neurons in the hippocampus $(\mathrm{K} 10,250 \times$, dark ground). 


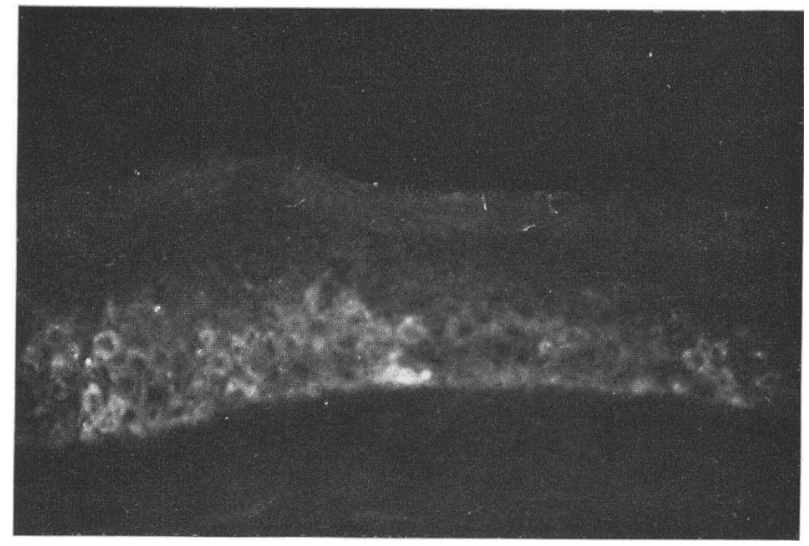

F i g u r e 12. Corneal epithelium (K 10, $250 \times$, dark ground). 

immunohistological pattern was characteristic (Fig. 5). Infected cells were mainly found in the glomeruli, whereas adjacent tubuli were usually unaffected. However, infected tubulus cells were found in the medullary rays.

The liver was examined in $\mathbf{1 7}$ cases. Infection was found only in the interstitial tissue and never involved the liver cells.

In the salivary glands (parotid) viral antigen was demonstrated in the secretory cells.

Blood vessels and lymphatic tissue. In all tissues, infected endothelial cells could be demonstrated in capillaries and larger vessels, but it was characteristic that the infection frequently involved also the media and adventitia (Figs. 6 and 7). Intense autofluorescence could mask the specific fluorescence in walls of vessels rich in elastic fibers, but the use of pure u.v.-light for excitation, in combination with a colourless barrier filter, made identification easier. Infected mononuclear cells were frequently seen in engorged vessels.

In H.E.-stained paraffin sections degenerative and inflammatory changes were often observed in the vascular walls. These changes were characterized by karyopyknosis and shrinking of media cells and sometimes by small focal infiltrations of mononuclears.

H.E.-staining of cryostat sections that had previously been stained by FA was attempted in order to relate the results of the FA-staining to the histological lesions, but this practice was soon abandoned as the cryostat sections were found quite unsatisfactory for conventional histological examination.

In the lymph nodes the pattern of fluorescence varied, ranging from a few fluorescent reticulum cells in the germinal centers to larger foci which could easily be detected by low-power magnification (Fig. 8).

In general the spleen was not very extensively involved. Infection was often confined to the vessels and a few scattered cells in the pulp. However, focal accummulation of viral antigen was observed in the germinal centers around the central arteries.

In the lymfoid component of the tonsils the distribution of fluorescence was similar to that found in the lymph nodes, but as a rule also the epithelium of the crypts was infected (Fig. 9).

Brain and eye. Infected cells were found in the brain in all of the 10 cases in which the brain was available for examination. In one case the infection was apparently confined to the vascular 
system, since only scattered infected endothelial cells were demonstrated. In the rest of the cases infected neurons were found.

Sections were prepared from the cerebrum, hippocampus, pons, and cerebellum. Among these sites the cerebral cortex and the hippocampus seemed to be most strongly affected (Figs. 10 and 11).

As in other cell types the specific fluorescence of the neurons was cytoplasmic, but the distribution appeared more uneven. In some neurons the antigen appeared as large conglomerations of fluorescent material localized excentrically in the cytoplasm. In others there were fine fluorescent granula close to the nucleus and along the dendrites and axons.

In the hippocampus infected cells were found in the molecular layer.

Slight changes, if any, were found by histological examination of formalin-fixed H.E.-stained sections of tissue blocks adjacent to those that had been examined by FA and in which virus had been demonstrated. Possible degenerative changes of neurons suggestive of viral multiplication could not be demonstrated by the simple histological technique used in this study.

None of the animals examined had shown any signs of corneal opacity, but by the use of FA large numbers of fluorescent cells were found in the corneal epithelium in 6 cases (Fig. 12).

Non-specific staining and autofluorescence. The absorption of conjugates with calf kidney powder proved to be sufficient to eliminate overconjugated globulins and possible antibodies to normal kidney cells. In the working dilution $1: 8$ to $1: 10$ there was no or only insignificant staining of the background when uninoculated primary calf kidney cultures and freshly cut sections of normal tissue were stained. The purification of the bovine conjugate by DEAE chromatography was equally efficient.

In the lymph nodes and in the intestinal wall non-specifically stained granulocytes occasionally occurred. However, there was enough difference in the colour and distribution of the fluorescence between these cells and infected cells to avoid mistake. When the colourless secondary filter was used the fluorescence of the granulocytes was greyish-green and could be even more intense than in specifically stained cells.

Control of staining specificity. On representative positive sections of the tissues mentioned previously the specificity of the staining was ascertained by the following tests: 
1) Inhibition of the staining reaction by unconjugated VDantiserum. A marked inhibition of the staining was seen when the conjugate was suitably diluted with unconjugated antiserum. Comparison was made with sections that had reacted with conjugates diluted in normal goat and cattle sera.

2) Testing of the conjugate on sections of fresh, normal tissue (various tissues from 14 different animals collected at a slaughterhouse). These sections did not stain with the conjugate. As the validity of normal tissues as controls for non-specific staining may be questioned, it should be added that sections of fresh tissues from 2 cases of bovine malignant catarrh (BMC) *) were also tested, and that none of these stained with the VD-conjugate.

3) Conjugated normal goat serum and pseudorabies antiserum, properly absorbed, did not stain tissues that had shown specific staining with VD-conjugate.

Several stainings of brain sections were performed in order to ascertain the specificity of the fluorescence of the neurons of the cerebral cortex and hippocampus. All the above-mentioned tests were satisfied, and staining of neurons was attained with conjugates of 3 different goat sera and a convalescent bovine serum. Normal brains (7 cases examined) and brains from two cases of bovine malignant catarrh (BMC) did not stain with the VD-conjugates.

\section{DISCUSSION}

The immunohistological examination of tissues from 59 cattle affected with BVD-MD revealed a distribution of viral antigen which agrees with the conception of this disease as a generalized virus infection caused by VD-virus.

Viral antigen could be demonstrated in all types of tissue examined, but the degree of involvement varied considerably. Infected cells were particularly abundant in the epithelia of the

*) The diagnosis of BMC was based on the following criteria: Both cases (heifers) came from herds in which there had been close contact between sheep and cattle. The animals had high fever, excessive salivation, lacrimation, and nasal discharge. There was complete corneal opacity of both eyes. Histological examination of the brain revealed encephalitis with perivascular infiltrations of round cells. There were also infiltrations of round cells in the interstitial tissues of the liver, kidneys, and lungs. 
oral and gastro-intestinal mucous mebranes, whereas the infection was much less pronounced in parenchymatous organs.

These findings were not unexpected, since Darbyshire (1967), by means of the agar-gel-diffusion technique, had found a similar distribution of soluble, precipitating antigen in animals affected with mucosal disease.

Histological studies by Hansen et al. (1962) suggested that the changes in the epithelia of the mucous membranes of the mouth and the gastro-intestinal tract were direct results of viral multiplication.

In BVD-MD as in many other generalized virus infections viral multiplication takes place in the endothelial cells of capillaries and larger vessels. But, in addition, the infection often involves the media and adventitia of the larger vessels. Several authors have noted the inflammatory and degenerative changes in the vascular system in BVD-MD (Trautwein 1965, Mills et al. 1968) and such changes were also found in the present material. Because of the frequent finding of infected cells in the vascular walls it is reasonable to assume that these changes are results of viral multiplication.

In view of the generalized nature of the infection it was not surprising to find infected cells in the brain, but it was unexpected that viral antigen could be found in the neurons in 9 out of 10 cases. The 6 animals from which the heads were examined had died and 4 had been killed in an advanced state of disease, but none of the animals had shown signs or symptoms that had been interpreted as indicative of cerebral disorder. However, nervous symptoms have been observed in cases of mucosal disease by Schipper et al. (1955).

By histological examination, Khater et al. (1964) found encephalitis in a few cases of mucosal disease, but also stressed that the changes were much less pronounced than in cases of bovine malignant catarrh.

As the terminal stages of BVD-MD are apparently characterized by an extensive involvement of the vascular system, the infection of the brain is likely to be of hematogenous origin, but a neural spread both to and from the central nervous system probably occurs to some extent.

The most frequent port of entry and primary site of multiplication of VD-virus under natural conditions are not known. The investigations reported on in the present paper do not per- 
mit any conclusions as to the way in which the infection has been established in the nasal and bronchial epithelium, but studies by Mills \& Luginbuhl (1968) have shown that aerogenous inoculation easily produces the experimental disease.

When the usual rules for carrying out FA-tests are observed, the direct demonstration of virus by FA in cryostat sections may be a valuable supplement to tissue culture techniques for diagnosis of BVD-MD on post-mortem material. 'The present report gives no basis for comparing direct demonstration of virus in sections with demonstration of virus by the tissue culture method; it should be pointed out, however, that attempts to cultivate VD-virus in primary calf kidney cultures were unsuccessful in 12 cases in which FA-stained sections had been clearly positive by immunohistological examination.

It is obvious that only tissue free from autolytic changes should be used for FA-staining. When this condition is satisfied negative staining results on sections of various tissues, including oral and intestinal mucosa, are probably significant. It seems most unlikely that antibodies in the tissues should interfere in the reaction between antigen and conjugate and thereby inhibit the staining reaction, since many investigators have demonstrated that animals affected with mucosal disease do not produce neutralizing antibodies against VD-virus (Borgen 1963, Bürki \& Germann 1964). The existing antigenic differences between strains of VD-virus that may perhaps be reflected in the staining results (Fernelius 1964) can hardly present any problems when potent conjugates are used.

\section{ACKNOWLEDGMENTS}

The author is indebted to dr. H. C. Borgen, State Veterinary Institute for Virus Research, Lindholm, for supplying the VD-virus strain UG59, to dr. V. Bitsch for supplying the primary calf kidney cultures, to Mrs. V. Christensen for preparing photographic prints and to Miss A. Wang for technical assistance.

\section{REFERENCES}

Basse, A.: Sektionsfundet ved „atypisk katarrhfeber“ hos kvæg. (The necropsy findings in atypical malignant catarrh in cattle). Nord. Vet.-Med. 1961, 13, 529-542.

Borgen, H. C.: Mucosal Disease in Dänemark II. Virologische und serologische Befunde in einem Bestand. (Mucosal disease in Denmark II. Virological and serological findings in a herd). Nord. Vet.-Med. 1963, 15, 346-356. 
Bürki, F. \& E. Germann: Letale pneumoenteritiden bei Kälbern verursacht durch den Erreger der bovinen Virus Diarrhoe. (Lethal pneumoenterides in calves caused by the exciter of bovine virus diarrhoea). Berl. Münch. tierärztl. Wschr. 1964, 77, 324$326,333-335$.

Darbyshire, J. H.: Immunodiffusion with bovine mucosal disease. J. comp. Path. 1967, 77, 107-115.

Dinter, Z. \& H. C. Borgen: Bovine virus diarrhoea (mucosal disease) virus in Swedish and Danish cattle. Nord. Vet.-Med. 1964, 16, $384-389$.

Fernelius, A. L.: Noncytopathogenic bovine viral diarrhea viruses detected and titrated by immunofluorescence. Canad. J. comp. Med. 1964, 28, 121-125.

French, E. L. \& W. A. Snowdon: Mucosal disease in Australian cattle. Aust. vet. J. 1964, 40, 99-105.

Gillespie, J. H., Patricia F. Bartholomew, R. G. Thompson \& K. McEntee: The isolation of noncytopathogenic virus diarrhea virus from two aborted fetuses. Cornell Vet. 1968, 57, 567-571.

Hansen, H.-J., O. Roneus \& Z. Dinter: Untersuchungen über Mucosal Disease. II. Pathologische Anatomie der Krankheit im Vergleich mit dem cytopathogenen Effekt des Virus der Virusdiarrhoe auf die Gewebekultur. (Studies on mucosal disease. II. Pathology of the disease in comparison with the cytopathic action of bovine diarrhoea virus). Zbl. Vet.-Med. (B) 1962, 9, $854-864$.

Khater, A. R., C. Messow \& M. Stöber: Der histopathologische Gehirn Befund als differentialdiagnostischer Hilfsmittel zur Abgrenzung von Mucosal Disease, bösartigen Katarrhalfieber und Rinderpest. (The histopathological lesions of the brain as a means for differential diagnosis of mucosal disease, malignant head catarrh and rinderpest). Dtsch. tierärztl. Wschr. 1964, 71, 127131.

Kokles, R., D. Urbanek, H. Liebermann \& A. F. Olechnowitz: Vergleichende fluoreszenzimmunologische Untersuchungen mit verschiedenen Virusstämmen der Mucosal Disease des Rindes. (Comparative fluorescence immunological and cytopathological investigations with various strains of bovine mucosal disease virus). Arch. exp. Vet.-Med. 1967, 21, 1295-1304.

Mengeling, W. L., D. E. Gutekunst, A. L. Fernelius \& E. C. Pirtle: Demonstration of an antigenic relationship between hog cholera and bovine viral diarrhea viruses by immunofluorescence. Canad. J. comp. Med. 1963, 27, 162-164.

Meyling, A.\& V. Bitsch: The diagnosis of pseudorabies by the fluorescent antibody technique. Acta vet. scand. 1967, 8, 360-368.

Mills, J. H. L. \& R. E. Luginbuhl: Distribution and persistence of mucosal disease virus in experimentally exposed calves. Amer. J. vet. Res. 1968, 29, 1367-1375.

Mills, J. H. L., R. E. Luginbuhl \& I. W. Nielsen: Experimental transmission of bovine mucosal disease using virus recovered from urine. Res. Vet. Sci. 1968, 9, 500-505. 
Nielsen, $K$.: Atypisk hatarrhfeber hos kvæg. (Atypical catarrhal fever in cattle). Nord. Vet.-Med. 1961, 13, 517-528.

Olafson, P., A. D. McCallum \& F. H. Fox: An apparently new transmissible disease of cattle. Cornell Vet. 1946, 36, 205-213.

Peter, C. P., J. R. Duncan, D. E. Tyler \& F. K. Ramsey: Cytopathogenic changes of lymphatic tissues of cattle with the bovine virus diarrhea - mucosal disease complex. Amer. J. vet. Res. 1968, $29,939-948$.

Ramsey, F. K. \& W. A. Chivers: Mucosal disease of cattle. N. Amer. Vet. $1953,34,629-633$.

Romvary, J.: Incidence of virus diarrhea among newborn calves. Acta vet. Acad. Sci. hung. 1965, 15, 341-347.

Schipper, I. A., D. F. Eveleth, R. I. Shumard \& S. H. Richards: Mucosal disease in cattle. Vet. Med. 1955, 50, 431-434, 450.

Schipper, I. A. \& D. F. Eveleth: Mucosal disease in calves. Vet. Med. $1957,52,73-75$.

Trautwein, G.: Vergleichende Untersuchungen über das Amaloid und Paramyloid verschiedener Tierarten. (Comparison of amyloid and paramyloid in various animal species. I. Histomorphology and tinctorial properties). Path. Vet. 1965, 7, 297-327.

Voss, H., G. Henneberg, G. Hermann, H. Pichl, S. Schulte-Overberg \& H. Werner: Die Kopplung von Immunseren mit Fluoresceinisothiocynat. (Conjugation of immunsera with fluoresceinisothiocyanate). Zbl. Bakt., I. Abt. Orig. 1967, 203, 249-276.

\section{SUMMARY}

An account is given of immunohistological studies performed on tissue specimens from 59 cattle affected with BVD-MD. The animals had either died or been killed in an advanced state of the disease. From 47 of these animals VD-virus was demonstrated in primary calf kidney cultures inoculated with suspensions of at least one of the following tissues: small intestine, lung, kidney, and spleen. Conjugates were produced from sera of goats that had been immunized with the Danish VD-virus strain UG59.

VD-virus could be demonstrated in all the types of tissue examined, but the degree of involvement was particularly high in the mucous membranes of the alimentary tract. It was characteristic that in all tissues viral antigen could often be demonstrated in the walls of blood vessels. In 9 out of 10 cases infected neurons were demonstrated in the cerebral cortex and hippocampus.

If fresh tissues are available for examination, FA-staining of cryostat sections may give a rapid diagnosis of BVD-MD.

\section{SAMMENDRAG}

Påvisning af VD-virus med fluorescerende antistoffer $i$ væv fra tilfælde af bovin virusdiarré (mucosal disease).

Der er udf $\phi r t$ immunohistologiske unders $\varnothing$ gelser af organpr $\phi$ ver stammende fra 59 dyr med BVD-MD. Dyrene var enten døde eller af- 
livet $i$ et fremskredent stadium af sygdommen. Fra 47 af disse tilfælde blev der påvist VD-virus i primære kalvenyrekulturer podet med vævssuspensioner fremstillet ud fra mindst et af følgende organer: tarm, lunge, nyre og milt. 'Til fremstilling af konjugater anvendtes gedesera, der var fremstillet ved hyperimmunisering af geder med den danske VD-virusstamme UG59.

VD-virus kunne påvises i alle vævstyper, men udbredelsen af infektionen bedømt efter antallet af inficerede celler varierede meget. VD-virus antigen var således til stede i særlig stor mængde i fordøjelseskanalens slimhinder. Det var karakteristisk, at der i de forskellige væv ofte kunne påvises inficerede celler i karvægge. I 9 ud af 10 unders $\varnothing$ gte tilfælde blev der påvist infektion af nerveceller i storhjernebarken og hippocampus.

Såfremt der foreligger frisk vævsmateriale til unders $\varnothing$ gelse, vil FA-farvning af kryostatsnit kunne give en hurtig diagnose af BVD-MD.

(Received May 27, 1969). 